\title{
Singing Activity for Mentally Disabled Children of St. Lusia Extraordinary School C in Deli Serdang Regency
}

\author{
Ance Juliet Panggabean ${ }^{1}$, Kamaluddin Galingging ${ }^{1}$ \\ ${ }^{1}$ Universitas HKBP Nommensen, Medan, North Sumatera, Indonesia. \\ Corresponding Author: Ance Juliet Panggabean
}

DOI: https://doi.org/10.52403/ijrr.20220227

\begin{abstract}
Mentally retarded children generally have problems in communication, interaction, and empathy. Children with mental retardation also look different physically, mentally and socially emotionally. Children with developmental delays physically, mentally, cognitively, the handling of these mentally retarded children requires a very special approach. The obstacles experienced by mentally retarded children make it difficult for them to do both homework, especially jobs that require expertise. But despite having obstacles they still have the ability to do simple jobs. To develop the abilities possessed by mentally retarded children, training and assistance are needed. With this training and assistance, it is hoped that mentally retarded children will have the ability to work. The training and mentoring are given specifically, step by step until the child is really able to master one job. Every child has different abilities, so a very adequate and varied training advice is needed. Research with the process of singing activities was carried out with several methods applied in data collection, namely: (1) observation method, (2) library method, (3) qualitative descriptive method. The singing activity was considered quite successful. Success indicators can be seen and evaluated through children's daily activity units which are recorded as a reference to determine the development and progress of children in each activity carried out.
\end{abstract}

Keywords: Singing activity, mentally disabled children, extra-ordinary school

\section{INTRODUCTION}

The Special School for Tunagrahita is a special school for mentally retarded children. Mental retardation is another word for mental retardation (mental retardation). Mental retardation means mentally retarded. According to the Japan League for Mentally Retarded (1992) mental retardation is a child whose intellectual function is slow, namely an IQ of 70 and below based on intelligence tests; deficiencies in adaptive behavior; This occurs during the developmental period, which is between the conception and the age of 18 years. (http://www.ditplb.or.id/new/index.phd).

Barriers possessed by mentally retarded children make them often considered a burden so that they often get less attention. Along with the development of science and human awareness, children with mental retardation are no longer considered to be a burden, but they are human beings who deserve the same respect as humans in general. They have the right to education for the development of independence so that they can live in the society in which they live.

Everyone basically wants a decent life. For this reason, various ways are sought to achieve a decent life. For people who have normal IQ abilities, getting a job for a decent life from an economic perspective is easier than for mentally retarded children. This is because mentally retarded children experience obstacles 
related to their intellectual abilities. The intellectual ability of mentally retarded children is below the normal average, one of which implies that mentally retarded children experience obstacles in adaptive behavior. One of the adaptive behaviors referred to is that mentally retarded children are unable to support themselves from an economic point of view (economic selfsufficiency). By understanding the barriers for mentally retarded children from an economic perspective, SLB-C seeks skills training.

The obstacles experienced by mentally retarded children make it difficult for them to do both homework, especially jobs that require expertise. But despite having obstacles they still have the ability to do simple jobs. To develop the abilities possessed by mentally retarded children, training and assistance are needed. With this training and assistance, it is hoped that mentally retarded children will have the ability to work. The training and mentoring is given specifically, step by step until the child is truly able to master one job. Every child has different abilities, so a very adequate and varied training advice is needed. Based on the analysis of the ability of children from SLB-C St. In singing activities, Lusia has a light class which was directly selected by Sister Beatris Sitinjak as the Principal of SLB-C St. Lucia Deli Serdang.

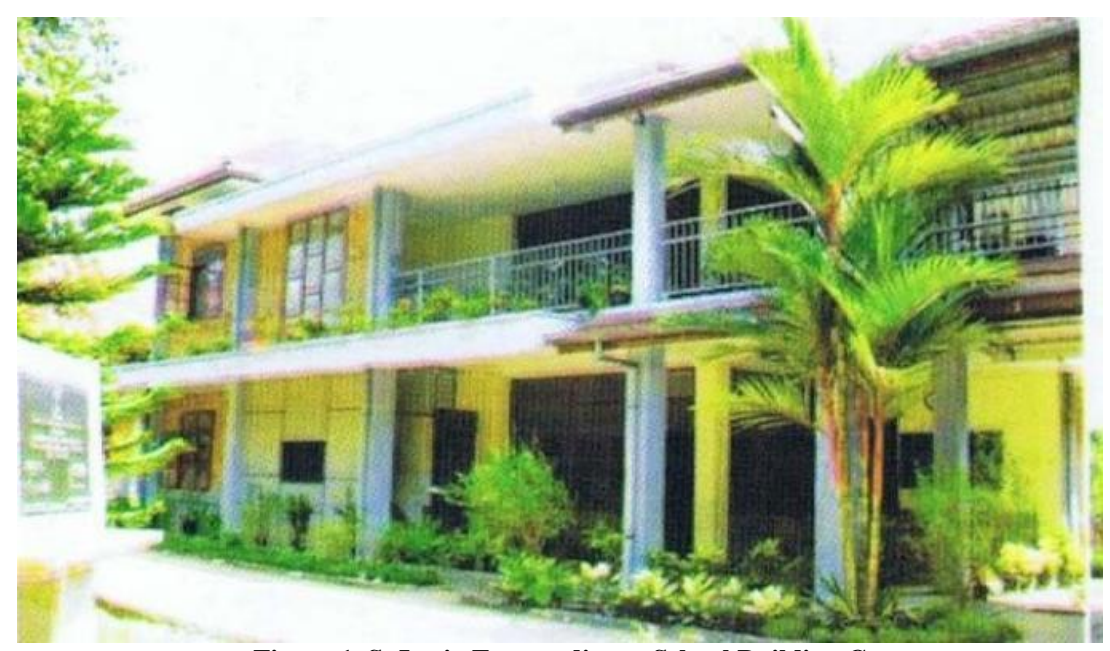

Figure 1. St Lusia Extraordinary School Building C

There are 17 light grade downsyndrome students who are involved in singing activities which will be trained by the research team. The names of these students, as shown in table 1 below:

Table 1. List of Students at St Lusia Extraordinary School C

\begin{tabular}{|l|l|l|l|l|}
\hline No & Students' Names & Sex & Age/Class & Health Record \\
\hline 1. & Debbienatalia Nainggolan & $\mathrm{F}$ & $18 /$ High School $(\mathrm{HS})$ & Down syndrome \\
\hline 2. & Elisabeth Sitorus & $\mathrm{F}$ & $14 / \mathrm{HS}$ & Down syndrome \\
\hline 3. & Ella Yona Ivanna Ginting & $\mathrm{F}$ & $13 / \mathrm{HS}$ & Down syndrome \\
\hline 4. & Firmanda Ompusunggu & $\mathrm{M}$ & $17 / \mathrm{HS}$ & Down syndrome \\
\hline 5. & Jaka Gunawan Silaban & $\mathrm{M}$ & $15 / \mathrm{HS}$ & Down syndrome \\
\hline 6. & Kevin Joel & $\mathrm{M}$ & $17 / \mathrm{HS}$ & Down syndrome \\
\hline 7. & Kristanty Sinaga & $\mathrm{F}$ & $16 / \mathrm{HS}$ & Down syndrome \\
\hline 8. & Maria Gonethi Halawa & $\mathrm{F}$ & $12 / \mathrm{HS}$ & Down syndrome \\
\hline 9. & Nelly Aprisari Aritonang & $\mathrm{F}$ & $22 / \mathrm{HS}$ & Down syndrome \\
\hline 10. & Novenda Samosir & $\mathrm{F}$ & $35 / \mathrm{HS}$ & Down syndrome \\
\hline 11. & Tri Purnama Hutasoit & $\mathrm{F}$ & $13 / \mathrm{HS}$ & Down syndrome \\
\hline 12. & Yudha Putra Gultom & $\mathrm{M}$ & $15 / \mathrm{HS}$ & Down syndrome \\
\hline
\end{tabular}

Singing activities at SLB C St. Lusia is held every Tuesday and Friday, 16.0017.00 WIB (outside school hours), in the
Music room of SLB A St. Lucia Deli Serdang. It is carried out outside school hours, so that mentally retarded children are 
not disturbed by school hours and other children's activities, such as eating lunch, sleeping, bathing, and studying. The atmosphere of the room is very comfortable for singing activities carried out. At each meeting, with the approach of training methods and mentoring singing activities can be carried out well.

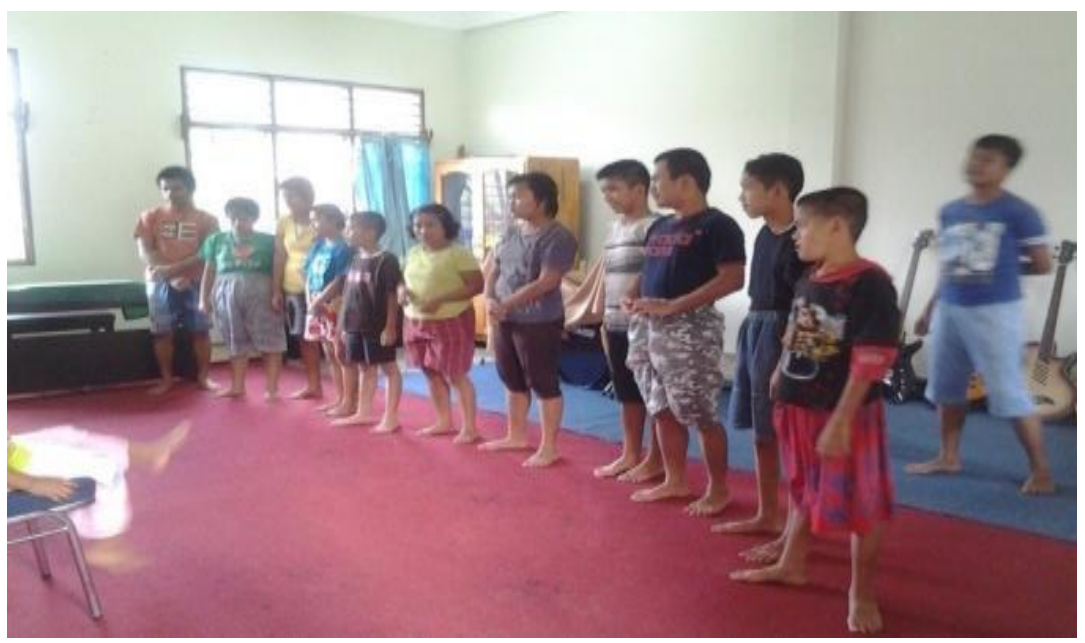

Figure 2. Briefing mentally retarded children before teaching and training process begins

In the activity of singing songs for mentally retarded children, the right method is needed as was done by the research team through teaching methods, training methods and mentoring methods. The research team gained a lot of experience through this activity, and the research team felt the need to develop it again to the level of research for mentally retarded children in singing activities in the years to come.

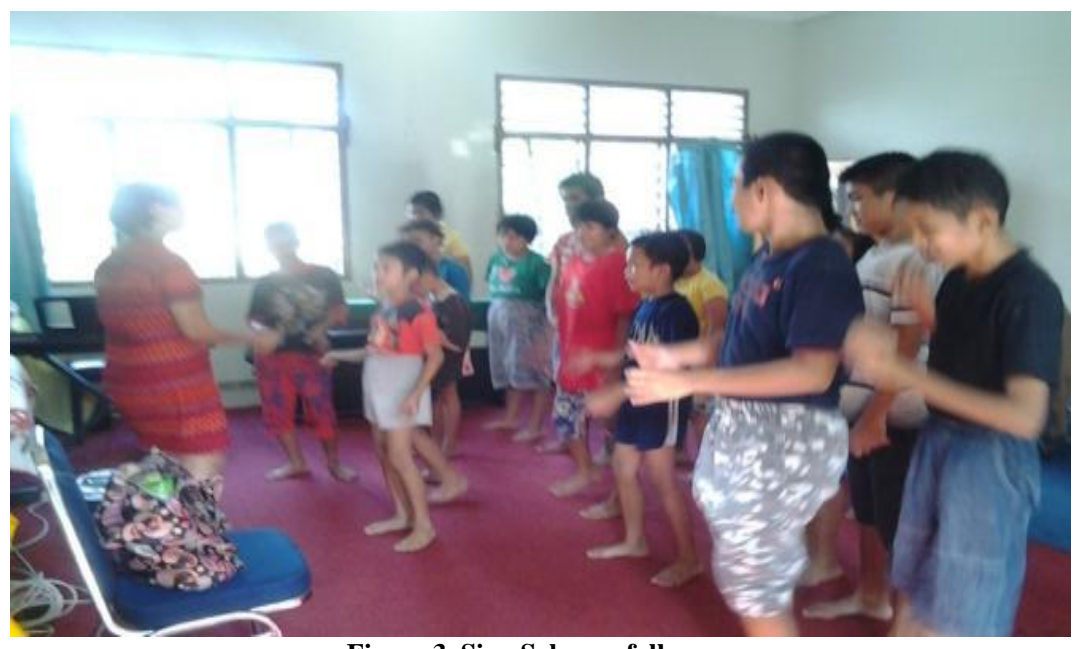

Figure 3. Sing Soleram folk song

It is not an easy matter to train with such children. As stated by Sister Beatris Sitinjak, it takes sacrifice of heart and taste, sacrifice of time, extraordinary patience, perseverance and tenacity. Children with mental retardation do not need bright intelligence, but a sincere, clear heart, full of love and compassion for life and highly dedicated in training. The background of mentally retarded children is a weak resource, has parents who are economically weak/poor and helpless. For mentally retarded children who do not have families, limited ability of parents to educate them, the very long distance between the homes where parents live and children with SLB-C are provided with orphanage services.

Barriers experienced by mentally retarded children require continuous early treatment so that they can develop their abilities to the fullest. To develop the ability of mentally retarded children, special 
education services are needed. In art activities, SLB-C St. Lusia often carries out artistic activities such as art performances and concerts. SLB-C ST. Lusia has a program of artistic activities, such as singing, dancing, playing music. They learn, are educated by teachers in various fields of science, one of which is art. Moreover, music lessons, music art is a subject that requires considerable understanding because in addition to theoretical lessons, students are also required to practice. Under such circumstances, the supervising teacher must always be in the classroom to help, assist students in the learning process.

1. Help children develop singing activities into a fun activity and approach to music learning for mentally retarded children;

2. Develop more creative and appropriate teaching methods for mentally retarded children;

3. Creating a comfortable teaching process in the classroom for mentally retarded children.

Singing activities for mentally retarded children have often been carried out by teachers at the SLB-C St. Lusia, but teaching for singing activities with folk songs and western songs has never been done. The problems faced by the school are: (1) not yet applying the correct teaching method for singing activities. (2) there is no special supervisor teacher for music lessons, because the school still entrusts and empowers internal teachers who do not have expertise in music (3) syllabus and daily activity plans or daily activity units for musical arts activities do not yet exist. (4) singing activities have been carried out but the teacher has never given material for folk songs and western songs, (5) factors for the nature and character of children, (6) factors from parents, who feel ashamed of the child's condition, thus affecting children's confidence in activities singing or performing from school. For this reason, the author and the team carried out several approaches to solving school problems.

Because mentally retarded children generally have problems in communicating, interacting and empathizing. Children with mental retardation also look different physically, mentally and socially emotionally. Children with developmental delays physically, mentally, cognitively, the handling of these mentally retarded children requires a very special approach.

Singing activities at SLB-C St. Lusia is held every Monday and Wednesday, at 16.00 WIB (outside school hours). Done outside school hours, so that mentally retarded children are not disturbed by school hours and other children's activities, such as eating lunch, sleeping, bathing, and studying. Conducted in a classroom measuring $4 \times 4$ meters. The atmosphere of the room is very comfortable for singing activities carried out. At each meeting, with an observation method approach to children with mental retardation. For educational activities, training and mentoring for singing activities cannot be carried out because mentally retarded children have full activities, so they require strong concentration and stamina to carry out activities considering that mentally retarded children have limitations.

Problems faced by SLB C St. Lusia, are: (1) have not applied the correct teaching method for singing activities. (2) there is no special supervisor teacher for music lessons, because the school still entrusts and empowers internal teachers who do not have expertise in music (3) syllabus and daily activity plans or daily activity units for musical arts activities do not yet exist. (4) singing activities have been carried out but the teacher has never given material for folk songs and western songs, (5) factors for the nature and character of children, (6) factors from parents, who feel ashamed of the child's condition, thus affecting children's confidence in activities singing or performing from school. While the second partner, SLB-C ST. Lusia has a program of artistic activities, such as singing, dancing, playing music. They learn, are educated by teachers in various fields of science, one of which is art, the most important in establishing cooperation 1 . Helping children develop singing activities 
into a fun activity and approach to learning the art of music for mentally retarded children, 2. Developing better teaching methods creative and appropriate for mentally retarded children, 3. Creating a comfortable teaching process in the classroom for mentally retarded children.

\section{Purposes of Singing}

The general purpose of singing activities is to be able to work together in singing activities to improve the skills or proficiency of mentally retarded children in singing songs in order to develop the potential of mentally retarded children in singing individually and collectively.

Specific goals of singing activities:

1. Provide educational methods and knowledge of teaching methods, which are very useful for teachers, especially to improve children's skills in singing songs.

2. Make a syllabus and plan activity programs with training methods, and mentoring methods for teachers so that they can support the singing activities that will be carried out.

3. Choosing repertoire as a learning resource with education and knowledge methods and mentoring methods for using repertoire in singing activities.

4. Provide skills training methods for singing techniques, so that good and correct singing techniques are produced.

5. Provide a method of singing training in stages on the use of the language contained in the poem.

6. Provide individual and collective singing mentoring and training methods for children with the aim of fostering children's self-confidence, such as not being awkward, shy, feeling inferior about their shortcomings, so that singing activities can be done with pleasure.

The benefits of the singing activity are by applying the right teaching methods and empowering potential human resources in the field of music, and implementing programmed syllabus and activity plans, as well as selecting the right song repertoire, a comfortable singing atmosphere will be created. and appropriate with good and correct teaching methods.

1. Using teaching methods, training, training and mentoring approaches. Teaching methods or learning models are through saying the words in song lyrics, singing while playing clapping, learning rhythm, learning melody, learning to play music, singing and listening to music (audio-visual). ) then singing activities are more pleasing to mentally retarded children;

2. Through individual and collective singing training for children with the aim of growing children's selfconfidence, such as not being awkward, shy, feeling inferior about their shortcomings, so that singing activities can be done with pleasure;

3. Increasing the self-confidence of mentally retarded children in singing folk songs and western songs and being more confident in their individual and collective performances.

\section{LITERATURE REVIEW Singing Activity}

Singing activities are carried out with an approach to teaching, training, and mentoring methods. This activity plan includes the following steps: Through activities by providing explanations of teaching methods for teachers and children, an educational and training approach is carried out so that partners have knowledge of good and correct teaching methods. Designing and making daily activity units for mentally retarded children, so that the plan or program of activities can be carried out as optimally as possible. The method is carried out through training and mentoring for schools so that they have the knowledge to make a syllabus or unit of daily activity plans, and an active role is expected in participating in each activity. Selection of repertoire as a learning resource for mentally retarded children through educational and mentoring methods so that 
mentally retarded children can say poetry in songs that use regional or foreign languages. Mentally Disabled Children

According to Bobby Ervani, et al: 2013, Children with mental retardation generally have problems in communicating, interacting and empathizing. Children with mental retardation also look different physically, mentally and socially emotionally. There are many children with physical, mental, cognitive developmental delays in various countries, including Indonesia, especially the city of Medan. In the city of Medan, attention to mentally retarded children has been going on for a long time and is starting to happen, this can be seen in the public's thinking that it is more open that these children must receive proper education in order to continue their independent life and change attitudes to a more positive attitude towards the problem of mentally retarded children., starting to provide services for mentally retarded children, such as schools and other educational services that are more flexible and accommodating to meet the diverse needs of students.

At this time mentally retarded children have received the same treatment as normal children in general, especially with the UNESCO program, namely EFA (Education for All) which means education for all. This motto aims to create educated humans from all types of circles, including children with mental retardation. Based on this motto, the government has provided special schools for mentally retarded children according to the type of physical and mental deficiency they have and their level of education. The special schools that have been provided by the government are SLB, SDLB, SMPLB, and SLTALB. In addition, there is one more school that accommodates mentally retarded children who are in the process of implementing their learning by combining mentally retarded children with regular students (normal children) in the same class and studying together. This school is called the inclusive school. (Bobby Ervani, et al: 2013, p. 24)

\section{National Education System}

In the 1945 Constitution Article 31 paragraph 1 and the Basic Law No. 2 of 1989 concerning the National Education system CHAPTER III paragraph 5 it is stated that "every citizen has the same opportunity to obtain education". This means that education has the right to be obtained by anyone, as well as children who have physical or mental disabilities who are also called mentally retarded children.

\section{MATERIALS \& METHODS Basic Methods}

The basic method that will be applied in this research is descriptive method. In other words, this research is intended to make a complete, factual and thorough description or description of the facts, nature and relationships between the phenomena being investigated. Furthermore, this method will underlie this research, especially in terms of data collection and data analysis.

\section{Data Collection Methods}

There are several methods applied in data collection, namely: observation method, library method, and qualitative descriptive method. The observation method is possible to compare what the informant said and what the informant did. Data was also collected by recording audio using an audio-visual recording device. The library method is expected to be able to obtain written data about the Singing Activities of Children with Mental Retardation SLB C St. Lusia Medan. Through a qualitative descriptive method to analyze the situation socially and described in an analysis to obtain conclusions according to the initial objectives of this study.

\section{Data Analysis Methods}

The data analysis procedure will be carried out through data selection; the data selection was carried out in order to select 
and summarize the data according to the needs of research on the Singing Activities of Children with Mental Retardation SLB C St. Lucia. Data classification is carried out to compile the basic data of certain criteria and divisions; meanwhile, data description, the data is described as well as possible so that a clear and detailed picture of the data is obtained, especially those that are relevant to the substance of the research. In case of interpretation, the interpretation of data seeks to find a relationship between the facts found and provides a clear understanding of the Singing Activities of Children with Mental Retardation SLB C St. Lucia. The final step is to draw conclusions, which is to briefly and concisely reaffirm what was found from the previous discussions.

\section{RESULT AND DISCUSSION}

The learning method used is the method of education, mentoring and training for singing activities to become a fun activity for mentally retarded children. At first, he explained that singing activities for mentally retarded children provide benefits and benefits for schools. 1. through singing while clapping, 2. pronouncing words in song lyrics, 3. learning rhythm, 4. learning melody, 5. Singing and listening to music (audio-visual). So that singing activities can be a fun activity for mentally retarded children. Learning theory or verbal explanations given by the team to the school must be followed by practical activities in the form of training so that the results or objectives are achieved properly. Therefore, after the team gave a theory or explanation about singing activities, the research team continued with training and mentoring.

The materials are focused on singing and clapping, learning rhythm and melody, breathing and vocal techniques, pronunciation, and singing and listening through audio-visual.

\section{Sing while clapping}

a. Play rhythm pattern by clapping.

Rhythm pattern 1: $\quad$ prok prok prok prok

Rhythm pattern 2: $\quad$ prok prok prok prok prok prok

Rhythm pattern 3: $\quad$ prok prok prok prok prok prok prok prok

\section{Rhythm Learning, Melody Learning:}

In this activity, mentally retarded children can imitate the sound or rhythm that the team did well. Then the mentally retarded child is trained to be able to imitate the sound that has been heard. Some simple rhythm patterns are taken from the song to be sung, the aim is to make it easier for mentally retarded children to recognize the rhythm of the song to be sung, for example the apuse song.

\section{*APUSE*}

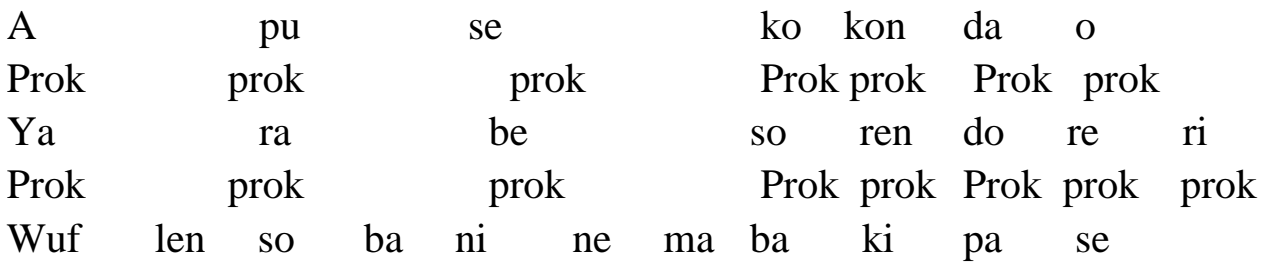

Prok Prok prok Prok prok prok prok Prok prok Prok prok

$\begin{array}{llllll}\text { A } & \text { ra } & & \text { fa } & \text { bye } & \text { A } \\ \text { Prok } & \text { Prok } & & \text { Prok } & \text { prok } & \text { prok } \\ \text { swa } & \text { ra } & \text { kwar } & & & \\ \text { prok } & \text { Prok } & \text { prok } & & & \\ \text { A } & \text { ra } & & \text { fa } & \text { bye } & \text { A } \\ \text { Prok } & \text { Prok } & & \text { Prok } & \text { prok } & \text { Prok } \\ \text { swa } & \text { ra } & \text { kwar } & & & \end{array}$


prok Prok prok

\section{Breathing Technique} children:

Diaphragmatic/abdominal breathing, examples are practiced for mentally retarded

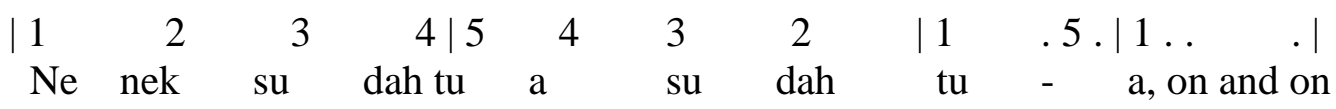

Breathing is the main element in singing. So for that, in singing activities for mentally retarded children it is necessary to use breathing techniques. The goal is to produce a beautiful sound. Singing breathing is not the same as normal breathing. Breathing in singing must be regulated properly, namely inhaling as much air as possible quickly, holding it for a moment, then exhaling very sparingly and consciously. (Center for Liturgical Music: 2011). The best way to breathe when singing is diaphragmatic breathing. Diaphragmatic breathing is located at the septum of the thoracic and abdominal cavities. Diaphragmatic breathing can be done in a way, the air in the lungs can be held without feeling tired so that the breath is issued sparingly and regularly by the diaphragm and the left and right side back muscles.

\section{Vocal Technique}

Learn vocal technique by pronunciation:

$\begin{array}{lllll}\text { a } & \text { i } & \text { u } & \text { e } & \text { o } \\ \text { aa } & \text { ii } & \text { uu } & \text { ee } & \text { oo } \\ \text { aaa } & \text { iii } & \text { uuu } & \text { eee } & \text { ooo } \\ \text { aaaa } & \text { iiii } & \text { uuuu eeee } & \text { oooo }\end{array}$

In singing activities, there is what is called a vocal technique. With good and correct vocal technique, singing will be more perfect. Vocal technique is a way of producing sound through the human voice in relation to the pronunciation of vowels such as a, i, u, e, o. By performing vocal techniques as a medium to produce a beautiful voice through: breathing, voice formation, articulation, phrasing and inspiration. For the results of vocal technique activities by mentally retarded children can be done well.

\section{Pronunciation of words in song lyrics}

Articulation or pronunciation, is also very important in singing. Words must be spoken well and clearly. Good and clear speech will also provide a clear understanding for listeners and vice versa poor and unclear pronunciation can damage the content of the song itself, so that it can unconsciously change the meaning of the song.

To beautify the utterance of these words can be arranged through the oral cavity and a good tongue position. It is necessary to pay attention to resonance techniques such as adjusting the shape of the mouth, the position of the lips, the position of the tongue so that it is a voice box. The position for pronouncing the vowel a, the mouth must be opened wide, namely as wide as when we yawn because we are sleepy or the width of the mouth can be entered with our three fingers. The tongue is slightly drawn in and the tip of the tongue does not touch the teeth. Pronouncing the vowel e, the mouth is opened smaller than the pronunciation of a then widen to the left and right. The pronunciation of the vowel e sounds resounding. Pronunciation i, the shape of the mouth is almost the same as the shape of the mouth pronouncing the vowel e, the difference is that the upper and lower lips are closer together and the sound is echoed. Pronunciation of the vowel o, the mouth is opened slightly wide and the lips are rounded, the tongue is pulled inward. Pronunciation of vowel $\mathrm{u}$, the mouth is opened smaller than the pronunciation of vowel a. for the results of the technical activities for the pronunciation of folk songs 
and western songs, they are good, but teacher assistance is still needed.

\section{Phrasing}

The phrasing means the rule of breaking song or musical lyrics into shorter parts, but still has a unified meaning. The purpose of phrasering is to cut sentences, both linguistic sentences and musical sentences more precisely according to meaningful unitary groups. Thus the effort to express a song can be closer to the truth contained in it according to the message of the song. For the results of the phrasering activity, mentally retarded children can do well.

\section{Singing and Listening through audio- visual}

Before singing, the research team carried out educational methods orally, about singing techniques, vocal techniques (articulation). The team gave an example orally and the mentally retarded child imitated it. In providing the training method, the research team prepared audio media, the purpose of which was to play folk songs and western songs specially selected for mentally retarded children. Through this audio media, folk songs and western songs or popular songs are played first, then repeated to be learned. The mentally retarded child will listen to the song that will be sung through this audio, such as a cd tape, youtube, mp 3 or mp 4, the goal is that the mentally retarded child can understand and recognize the characteristics and music of the song. Usually the song that will be sung is played repeatedly so that the mentally retarded child can remember the melody, rhythm and music contained in it. The results obtained from this activity, in this activity, mentally retarded children quickly catch and interact with the song that is played.

\section{CONCLUSION}

The implementation of the singing activity process is carried out using a learning model both verbally and theoretically, which is applied through education, training and mentoring methods. Through teaching methods both orally, theory and practice (demonstration) in singing folk songs is considered quite successful. Indicators of success can be seen and evaluated through children's daily activity units recorded by the research team as a reference to determine the development and progress of children in each activity carried out. The evaluations carried out were described on an individual and collective basis, and the most important of the learning outcomes carried out was through the implementation of the Music Colloquium which ran smoothly and successfully. In the process of singing activities for mentally retarded children SLB-C St. Lusia can be seen in the Daily Activity Unit which is described based on the theme that is carried out at each meeting. The research team is fully aware that the theory or verbal explanation given by the team to the SLB-C St. Lusia must be followed by practical activities in the form of training so that the results or objectives are achieved properly. Therefore, after the research team gave a theory or explanation about singing activities, they continued with training and mentoring. The singing activities include: sing and clap, rhythm and melody learning, breathing and vocal techniques, pronouncing words in song lyrics, and singing and listening to music through audio-visual. In the training to sing songs, children are invited to play while learning. Through activities that are fun for them, they will be willing and able to carry out singing activities with joy. As a coach, what needs to be considered is the condition and situation of the child when studying.

Acknowledgement: None

Conflict of Interest: None

Source of Funding: None 


\section{REFERENCES}

1. Bobby Ervani, dkk. 2013. Pembelajaran Musik bagi Anak Berkebutuhan Khusus di SMP NEGERI 4 Payakumbuh. E-Jurnal Sendratasik FBS Universitas Negeri Padang, vol. 2, no. 1. Seri E.

2. Busthomi, M. Yazid. 2012. Panduan Lengkap Paud Melejitkan Potensi dan Kecerdasan anak Usia Dini. Cetakan pertama. Penerbit Citra Publishing

3. Campbell, Don. 2011. Efek Mozart Memanfaatkan kekuatan Musik untuk Mempertajam Pikir, Meningkatkan Kreativitas, dan Menyehatkan Tubuh. Jakarta : Gramedia ustaka Utama

4. Dewi. P. Mahargyantari. 2009. Studi Metaanalisis: Musik untuk Menurunkan Stres. Jurnal psikologi. Vol. 36, no. 2, desember 2009: 106-115. Fakultas Psikologi universitas Gunadarma.

5. Djohan. 2009. Psikologi Musik. Yogyakarta: Penerbit Best Publisher

6. Gordon. E. Edwin, 1990. A Music Learning Theory for Newborn and Young Children. Chicago: GIA Publications, Inc.

7. Pekerti, Widia, dkk. 2010, Metode pengembangan Seni. Modul. Cet.12. Jakarta : universitas Terbuka.

How to cite this article: Ance Juliet Panggabean, Kamaluddin Galingging. Singing activity for mentally disabled children of St. Lusia Extraordinary School C in Deli Serdang Regency. International Journal of Research and Review. 2022; 9(2): 189-198. DOI: https:// doi.org/10.52403/ijrr.20220227 